\title{
Strategi Pengembangan Usaha Biskuit Jagung Di Kelompok Wanita Tani Lestari Desa Subun Tua'lele Kecamatan Insana Barat Kabupaten Timor Tengah Utara
}

Delfiana Kolo ${ }^{\mathrm{a}}$, Adelina Norawati Hutapea ${ }^{\mathrm{b}}$

${ }^{a}$ Fakultas Pertanian, Universitas Timor, Kefamenanu, Indonesia

${ }^{b}$ Fakultas Pertanian, Universitas Timor, Kefamenanu, Indonesia

\section{Article Info}

Article history:

Received 27 Mei 2016

Received in revised form 4 Juni 2016

Accepted 24 Juli 2016

\section{Keywords:}

Strategi Pengembangan Usaha

Biskuit Jagung

Wanita Tani Lestar

Subun Tua'lele

\begin{abstract}
Abstrak
Penelitian ini bertujuan untuk mengetahui gambaran umum usaha biskuit jagung di Kelompok Wanita Tani Lestari Desa Subun Tualele Kecamatan Insana Barat, dan untuk mengetahui strategi pengembangannya. Metode analisis data yang digunakan adalah 1) Analisis Deskriptif Kualitatif untuk mengetahui gambaran umum strategi pengembangan usaha biskuit jagung; 2) Analisis SWOT untuk mengidentifikasi faktor internal dan eksternal yang menjadi kekuatan, kelemahan, peluang dan ancaman dalam pengembangan usaha biskuit jagung. Berdasarkan hasil penelitian dalam pembahasan dapat disimpulkan bahwa kelompok wanita tani lestari merupakan salah satu kelompok tani yang berada di desa subun tualele, kecamatan insana barat, yang di bentuk pada Tahun 2000, dan melakukan usah biskuit jagung pada Tahun 2012, yang semua anggotanya terdiri dari para wanita dalam melakukan kegiatan usaha melalui pengolahan jagung menjadi biskuit jagung. Berdasarkan hasil penelitian dari analisis SWOT di peroleh titik koordinat $(0,86,1,02)$ yang mana koordinat ini berada pada kuadran 1 (agresif), artinya usaha biskuit jagung pada kelompok Wanita Tani Lestari memiliki kekuatan dan peluang yang sangat baik, sehingga Kelompok Wanita Tani Lestari dapat memanfaatkan peluang dan kekuatan yang ada untuk mengembangkan usaha biskuit jagung selanjutnya. Mariks SWOT menghasilkan 4 alternatif strategi yaitu WT1,WT2,WT3,WT4.dan analisis QSPM di gunakan untuk mengevaluasi dan memilih strategi-strategi terbaik yang paling utama di lakukan Kelompok Wanita Tani Lestari dalam mengembangkan usaha biskuit jagung yaitu strategi 1 (WT3). II (WT1), III (WT4), IV (WT2). (O2016 dipublikasikan oleh Agrimor.
\end{abstract}

\section{Pendahuluan}

Sektor pertanian merupakan salah satu sektor yang potensial, dan berperan penting dalam memperkuat landasan peningkatan kesejahteraan masyarakat Upaya pengembangan potensi pertanian dapat dilakukan dengan meningkatkan penghasilan dari komoditi-komoditi andalan sesuai dengan kondisi lokal.

Peningkatan produksi pertanian tidak akan memberikan kontribusi bagi pembangunan ekonomi nasional apabila tidak dimanfaatkan sebagai salah satu bahan baku bagi usaha industri. usaha industri yang berbahan baku tanaman pangan berperan untuk meningkatkan diversifikasi pangan bagi masyarakat sehingga dapat meningkatkan selera karena yang disediakan dalam beberapa bentuk.

Manfaat ekonomis yang diharapkan dari keberadaan usaha adalah meningkatkan kesempatan kerja, nilai tambah wilayah, pembangunan bag masyarakat, dan peningkatan mutu hasil produksi pertanian. Pengembangan usaha industri di pengaruhi oleh permintaan pasar, sehingga peningkatan daya beli dalam skala yang besar, sedang maupun usaha kecil.

Usaha adalah bagian dari industri kecil yang diusahakan terutama untuk menambah pendapatan keluarga. dan juga sebagai bagian dari agribisnis yang memproses dan mentransformasikan hasil pertanian menjadi barang jadi dan setengah jadi yang langsung di konsumsi, dan bahan bku usaha yang digunakan dalam proses produksi selanjutnya. kebutuhan akan pangan ini berlangsung sepanjang waktu, sehingga dengan adanya usaha pengolahan produk pertanian dapat menyediakan kebutuhan bagi konsumen.

Salah satu kelompok tani yang mengembangkan usaha di Desa Subun Tua'lele Kecamatan Insana Barat adalah kelompok Wanita Tani Lestari dengan usaha adalah Biskuit Jagung. Jenis jagung yang digunakan yaitu jagung mutiara (flint corn) - Zea mays indurate atau jagung kuning merupakan jenis jagung yang mempunyai sifat-sifat lebih baik dari pada jenis-jenis lainnya. Sifat penting yang dimiliki itu berpotensi hasil tinggi, berumur pendek (genjah), dapat menyerap pupuk sebaik mungkin dan tahan terhadap hama maupun penyakit (Rukmana, 2009), jagung ini juga di tanam sebagai pakan ternak (hijauan mau pun tongkolnya), dibuat tepung (dari bulir, dikenal dengan istilah tepung jagung atau maizena), dan bahan baku industri (dari tepung bulir dan tepung tongkolnya). Usaha Biskuit jagung merupakan salah satu hasil olahan jagung yang mempunyai kandungan gizi yang cukup baik. kandungan gizi biskui jagung meliputi: lemak, Protein, dan karbohidrat. dengan adanya usaha biskuit jagung yang maju ini, mampu memotivasi petani untuk meningkatkan produksi pertanian, dan memberi nilai tambah untuk meningkatkan kesejahteraan petani.

Kelompok Wanita Tani Lestari merupakan salah satu kelompok yang di bentuk sejak Tahun 2000, dengan jumlah anggota 16 orang. usaha yang dilakukan oleh anggota kelompok Wanita Tani Lestari adalah usaha biskuit jagung yang sudah berkembang sejak tahun 2012 hingga saat ini.

Usaha biskuit jagung merupakan salah satu usaha pengolahan bahan pangan yang berasal dari jagung, yang dihasilkan dari penggilingan jagung menjadi tepung jagung. usaha biskuit jagung ini dalam satu kali produksi membutuhkan bahan baku tepung jagung adalah sebanyak $1 \mathrm{~kg}$ yang menghasilkan 15 bungkus Biskuit Jagung, dengan harga per bungkus Rp.15.000.

Bahan baku yang digunakan dalam pengolahan usaha biskuit jagung yaitu tepung jagung, tepung terigu, telur, gula, fanili, royal, margarine dan santan kelapa. Kelompok Wanita Tani Lestari, pernah mewakili TTU di Sumba Bara dan mewakili NTT di Malang dengan membawa hasil olahan Biskuit Jagung dari bahan pertanian yang siap di konsumsi oleh konsumen.

Data sekunder yang di peroleh dari kelompok tani pada 3 Tahun terakhi (2012-2014) menunjukkan produksi usaha biskuit jagung dari tahun ke tahun mengalami peningkatan yaitu tahun 2012 produksi biskuit jagung sebanyak 360 bungkus, tahun 2013 produksi biskuit jagung 400 bungkus, dan pada Tahun 2014 produksi biskuit jagung 500 bungkus.
Masalah umum yang dihadapi dalam pengembangan usaha biskuit jagung, di Kelompok Wanita Tani Lestari, yaitu rendahnya SDM petani, teknolog produksi yang masih semi modern, dan terbatasnya sarana produksi. Berdasarkan uraian dari latar belakang di atas maka dianggap perlu untuk dilakukan penelitian dengan judul Strategi Pengembangan Usaha Biskuit Jagung Di Kelompok Wanita Tani Lestari Desa Subun Tua'lele Kecamatan Insana Barat Kabupaten Timor Tengah Utara.

\section{Metode}

Penelitian ini dilakukan selama tiga bulan dari bulan Maret-Mei 2016 Penentuan sampel dilakukan secara purposive sampling (sengaja) pada kelompok Wanita Tani Lestari dengan pertimbangan bahwa ketua kelompok saja yang di wawancarai, dengan alasan bahwa ketua kelompok yang lebih tahu tentang pengolahan biskuit jagung. Jenis data yang digunakan dalam penelitian ini adalah data primer dan data sekunder. Metode analisis data yang digunakan adalah 1) Analisis Deskriptif Kualitatif sesuai petunjuk Nazir (1988) untuk mengetahui gambaran umum strategi pengembangan usaha biskuit jagung; 2) Analisis SWOT untuk mengidentifikasi faktor internal dan eksternal yang menjadi kekuatan, kelemahan, peluang dan ancaman dalam pengembangan usaha biskuit jagung sesuai petunjuk Rangkuti (2001).

\section{Hasil dan Pembahasan}

\subsection{Proses Pembuatan Biskuit Jagung}

\section{Pemilihan Jagung}

Jagung yang digunakan dalam pembuatan biskuit jagung adalah jagung kuning yang sudah dijemur kering.

2. Pembersihan

Jagung kering ini kemudian di luruh dan kemudian di tapis dengan menggunakan nyiru sampai bersih.

3. Penumbukan

Jagung yang telah dibersihkan kemudian dihaluskan dengan cara ditumbuk dengan tujuan untuk memisahkan kulit ari dengan isinya. Alat yang digunakan adalah lesung atau alu. Saat proses penumbukan, jagung yang ada dalam lesung diisi air. Fungsi air ini adalah untuk melarutkan kulit jagung sehingga terpisah dari isinya. Setelah itu di keringkan.

4. Pengeringan

Jagung tersebut setelah itu di keringkan, \pm 30 menit. Sampai jagung tersebut benar-benar kering.

5. Penggilingan

Jagung yang ditumbuk tadi setelah dikeringkan kemudian dimasukan ke dalam mesin penggiling, supaya digiling sampai halus menjadi tepung jagung. Mesin yang digunakan sangat mudah sehingga kelompok wanita lestari tidak menggunakan tenaga pria.

6. Pengayakan.

Jagung yang telah halus tadi kemudian diayak ke dalam baskom dengan menggunakan alat pengayak sehingga bulir-bulir jagung yang kasar terpisah dengan tepung jagung

7. Pencampuran

Tepung jagung tersebut kemudian dicampurkan bahan baku yang lain seperti susu bubuk, telur, gula halus, fanili, dan royal, ke dalam baskom yang tela disediakan, kemudian proses mixer selama 15 menit. Masukan tepung jagung dan tepung terigu ke dalam adonan lalu di ramas selama \pm 20 menit.

8. Pencetakan

Proses pencetakan ini dilakukan saat campuran adonan sudah merata. Pencetakan dilakukan dengan menggunakan alat pencetak biskuit. Dan cetakan ini sesuai selera yang di inginkan. Setelah itu di letakan pada Loyang yang telah di lapisi margarine. 


\section{Pengovenan.}

Proses pengovenan setelah dicetak kemudian di masukan ke dalam oven dengan suhu $218^{\circ}-232^{\circ} \mathrm{C}$ dalam waktu $15-20$ menit. Setelah benar-benar kering dan matang, angkat dan letakkan pada nampan berlapis yang telah disediakan. Biskuit jagung yang telah matang tersebut kemudian di masukan ke dalam baskom kemudian di diamkan sampai dingin.

10. Pengemasan

Biskuit jagung yang sudah matang atau dingin kemudian dikemas dalam plastik aluminium foil setelah itu di pres lalu ditempel label di depan untuk di jual. Pengemasan ini dilakukan dengan menggunakan plastik bening aluminium foil dengan tujuan untuk melindungi biskuit jagung agar tidak mudah rusak. Biskuit jagung yang sudah dikemas kemudian disimpan pada efalase agar aman. 11. Pemasaran biskuit jagung

Pemasaran merupakan langkah atau tahap akhir dari usaha biskuit jagung. Berdasarkan hasil wawancara pemasaran biskuit jagung hasil produksi di lakukan langsung di kelompok wanita tani lestari, di jual ke swalayan terdekat, di pameran- pameran, dan di kantor-kantor pada saat gajian pegawai.

\subsection{SWOT}

Untuk menganalisis faktor-faktor pengembangan usaha biskuit jagung di kelompok wanita tani lestari di lakukan analisis SWOT. Analisis ini dilakukan dengan mengamati faktor-faktor lingkungan baik internal (kekuatan dan kelemahan), dan eksternal (peluang dan ancaman) yang di miliki oleh usaha biskuit jagung di kelompok wanita tani lestari. Faktor internal (kekuatan dan kelemahan) dan faktor eksternal (peluang dan ancaman) dapat di identifikasi sebagai berikut a) Kekuatan; b) Kontinuitas produksi; c) Kebersamaan dalam kelompok; d) Sudah lama mengusahakan; e) Memiliki kekhasan produk dari segi rasa, tekstur dan penampilan produk; f) Ketersediaan bahan baku; g) Kelemahan h) Rendahnya kualitas SDM; i) Teknologi produksi; j) Promosi belum efektif; k) Daya simpan produk; 1) Kurangnya modal; m) Belum memiliki surat ijin usaha; n) Belum memiliki Surat ijin BPOM; o) Peluang; p) Dukungan PEMDA; q) Tersedianya pasar; r) Produk lokal; s) Banyak konsumen di luar daerah; t) Kondisi lingkungan mendukung; u) Ancaman; v) Persaingan; w) Perubahan selera konsumen; $\mathrm{x}$ ) Harga bahan baku penolong semakin tinggi, dan y) Penolakan produk.

Model yang digunakan adalah Matriks factor strategi internal (IFAS) dan matriks factor strategi eksternal (EFAS). Hasil identifikasi faktor-faktor internal yang merupakan kekuatan dan kelemahan, rating dan pembobotan dipindahkan ke tabel matriks IFAS untuk diberi skoring (rating $\mathrm{x}$ bobot), pada Tabel 1 .

Tabel 1. Matriks Evaluasi Faktor Strategi Internal (IFAS)

\begin{tabular}{lccc}
\hline \multicolumn{1}{c}{ Faktor internal } & Rating & Bobot & Skor \\
\hline Kekuatan ( strength) & & & \\
Kontiunitas produksi & 3 & 0.17 & 0.51 \\
Sudah lama mengusahakan & 3 & 0.17 & 0.51 \\
Kebersamaan dalam kelompok & 4 & 0.22 & 0.88 \\
Memiliki kekhasan produk dari segi rasa, & & & \\
tekstur dan penampilan produk & 4 & 0.22 & 0.88 \\
Ketersediaan bahan baku & 4 & 0.22 & 0.88 \\
$\quad$ & & & \\
$\quad$ Total skor kekuatan & 18 & 1.00 & 3.66 \\
\hline Kelemahan (weakness ) & 3 & 0.15 & 0.45 \\
Teknologi produksi & 4 & 0.20 & 0.80 \\
kualitas SDM & 2 & 0.15 & 0.45 \\
Promosi belum efektif & 3 & 0.15 & 0.45 \\
Daya simpan produk & 3 & 0.15 & 0.45 \\
Kurangnya modal & 2 & 0.10 & 0.10 \\
Belum memiliki surat ijin usaha & 2 & 0.10 & 0.10 \\
Belum memiliki surat ijin BPOM & 19 & 1.00 & 2.8 \\
\hline$\quad$ Total skor kelemahan & & 0.86 \\
\hline$\quad$ Selisih kekuatan - kelemahan & &
\end{tabular}

Sumber : Data Primer Diolah, 2016

Berdasarkan hasil penentuan skor (rating x bobot) untuk faktor internal: kekuatan (strength) pada Tabel 1. yang memiliki rating tertinggi (4) artinya faktor internal kekuatan yang paling kuat dan menguntungkan, faktor-faktor tersebut adalah adalah : . 1). Kebersamaan dalam kelompok, artinya dalam memproduksi biskuit jagung selalu melibatkan anggota kelompok sehingga besarnya permintaaan konsumen selalu terpenuhi. 2). Ketersediaan bahan baku, artinya dalam memproduksi biskuit jagung bahan baku selalu tersedia sehingga tidak mengalami kesulitan. 3). Memiliki kekhasan produk dari segi rasa,tekstur, dan penampilan produk artinya selama ini biskuit jagung yang di produksi kelompok wanita tani lestari selalu sesuai keinginan konsumen,dan memiliki tekstur yang sangat lembut, dan dalam penampilan produknya sangat bagus sehingga dapat menarik banyak konsumen. Sedangkan faktor internal kekuatan lainnya memiliki rating (3) artinya menguntungkan bagi kelompok wanita tani lestari. Faktor-faktor tersebut di antaranya adalah : 1). Kontiunitas produksi artinya kontiunitas produksi saat ini cukup berjalan dengan baik karena tercukupinya ketersedian bahan baku sehingga kelompok wanita tani lestari tidak kesulitan dalam memproduksi biskuit jagung. 2). Sudah lama mengusahakan artinya kelompok wanita tani lestari ini sudah cukup lama \pm 4 tahun mengusahakan dan sudah cukup berpengalaman dalam memproduksi usaha biskuit.

Berdasarkan hasil penentuan skor (rating $\mathrm{x}$ bobot ) pada faktor internal kelemahan ( weakness ) pada tabel di atas yang memiliki rating (4) artinya faktor internal kelemahan yang terendah atau kurang baik, faktor-faktornya adalah: 1). Kualitas SDM artinya selama ini kelompok wanita tani lestari dalam pengolahan jagung dengan produk unggulan biskuit jagung yang kurang berkualitas, hal ini dapat di lihat dari tingkat pendidikan, pengalaman kerja atau skill pada kelompok wanita tani lestari, dalam memproduksi biskuit jagung. faktor internal kelemahan (weakness) yang memiliki rating (3) artinya faktor internal kelemahan yang cukup baik adalah: 1). Teknologi produksi artinya selama ini teknologi yang di gunakan kelompok wanita tani lestari masih menggunakan teknologi modern. 2). modal artinya modal yang digunakan kelompok wanita tani lestari cukup sedikit dalam produksi biskuit jagung. 3). Daya simpan produk artinya hasil produksi biskuit jagung ini juga mempunyai daya simpan yang kurang cukup lama.. dan yang memiliki rating cukup rendah (2) pada faktor internal kelemahan adalah: 1). Promosi artinya selama ini promosi yang di lakukan oleh kelompok wanita tani lestari belum maksimal, 2). Belum memiliki surat ijin usaha artinya belum memiliki surat ijin usaha untuk kelompok wanita tani lestari dalam memproduksi biskuit jagung. 3). Belum memiliki surat ijin BPOM artinya sejauh ini kelompok wanita tani lestari belum memiliki nomor kesehatan dari balai besar pengawasan obat-obatan dan makanan (BPOM), sehingga berdampak negatif pada volume penjualan.

Tabel 2. Matriks Evaluasi Faktor Strategi Eksternal (EFAS)

\begin{tabular}{llll}
\multicolumn{1}{c}{ Faktor eksternal } & Rating & Bobot & Skor \\
\hline Peluang ( opportunities) & & & \\
Dukungan PEMDA & 4 & 0.22 & 0.88 \\
Tersedianya pasar & 4 & 0.22 & 0.88 \\
Produk lokal & 3 & 0.17 & 0.51 \\
Banyak konsumen luar daerah & 4 & 0.22 & 0.88 \\
Kondisi lingkungan mendukung & 3 & 0.17 & 0.51 \\
\hline Total skor peluang & 18 & 1.00 & 3.66 \\
\hline Ancaman (Threaths ) & & & \\
Persaingan & 3 & 0.25 & 0.75 \\
Perubahan selera konsumen & 4 & 0.33 & 0.80 \\
Harga bahan baku penolong semakin & 2 & 0.17 & 0.34 \\
tinggi & 3 & 0.25 & 0.75 \\
Penolakan produk & 12 & 1.00 & 2.64 \\
\hline Total skor ancaman & & & 1.02 \\
\hline Selisih pelung - ancaman & & &
\end{tabular}

Berdasarkan hasil penentuan skor ( rating x bobot) untuk faktor eksternal peluang (opportunity) pada Tabel 2. yang memiliki rating tertinggi (4 ) artinya memiliki peluang yang sangat menguntungkan. Faktor-faktornya adalah 1). Dukungan pemda artinya, selama ini PEMDA sangat mendukung upaya pengembangan kelompok pengolahan biskuit jagung, dengan cara memberikan pelatihan kepada kelompok wanita tani lestari dan memberikan kesempatan kerja sama dengan lembaga-lembaga lain, memberikan bantuan berupa peralatan yang digunakan untuk memproduksi biskuit jagung, dan kontribusi PEMDA khususnya dinas perindakop,dinas pertanian kab.TTU dalam membantu memasarkan biskuit jagung yang di produksi oleh kelompok wanita lestari. 2). Tersedianya pasar artinya pasaran untuk biskuit jagung selalu tersedia selain menitipkan di toko swalayan terdekat di dalam daerah kab.TTU maupun di luar daerah sehingga kelompok wanita tani lestari tidak merasa kesulitan dalam memasarkan biskuit jagung. 3). Banyak konsumen di luar daerah artinya biskuit jagung ini banyak di minati oleh masyarakat luar daerah karena kelompok wanita tani lestari sudah memiliki jaringan pemasaran yang baik sehingga bukan hanya konsumen di dalam daerah saja, tetapi banyak konsumen di luar daerah yang dapat menikmati biskuit jagung milik kelompok wanita tani lestari.dan untuk faktor internal peluang lainnya memiliki rating (3) artinya memiliki peluang yang cukup menguntungkan adalah 1). Produk lokal artinya sejauh ini banyak konsumen yang tertarik dengan biskuit jagung karena hasilnya dari bahan lokal. 2). Kondisi lingkungan mendukung artinya kondisi lingkungan sekitar mendukung upaya pengembangan usaha biskuit jagung di kelompok wanita tani lestari karena lingkungan sekitar bersih dan cocok untuk memproduksi biskuit jagung.

Berdasarkan hasil perhitungan (rating $\mathrm{x}$ bobot) untuk faktor eksternal ancaman pada tabel 2 di atas yang memiliki rating (4) adalah 1). Perubahan selera konsumen artinya sejauh ini kelompok wanita tani lestari dalam memproduksi biskuit jagung ini belum pernah menemukan perubahan selera pada konsumen yang berkaitan dengan rasa biskuit jagung. Dan berdasarkan hasil perhitungan (rating $\mathrm{x}$ bobot) untuk faktor eksternal ancaman (threats) pada tabel 2 di atas yang memiliki rating (3) adalah 1). persaingan artinya produk biskuit jagung dapat bersaing dengan produk lain tetapi kelompok wanita tani lestari selalu mempertahankan persaingan melalui pembuatan produk unggulan dengan menghasilkan produk yang berkualitas dan terus menjaga dan meningkatkan kualitas produk. 2). Penolakan produk artinya tidak ada penolakan produk dari konsumen berkaitan dengan biskuit jagung yang di hasilkan kelompok wanita tani lestari karena dalam satu kali produksi selalu habis terjual. Yang memiliki 
rating terendah 2 adalah (1). Harga bahan baku penolong semakin tinggi artinya sejauh ini harga bahan baku penolong pembuatan biskuit jagung ini tidak menetap,dalam hal ini, harga bahan baku penolong berubah-ubah, sehingga menjadi ancaman.

Berdasarkan analisis terhadap faktor internal dan faktor eksternal yang berpengaruh dalam usaha biskuit jagung di kelompok Wanita Tani Lestari, di peroleh skor pembobotan pada faktor internal kekuatan (strength) sebesar 3,66, faktor kelemahan (weakness) 2,8 sedangkan untuk faktor peluang (opportunity) 3,66 dan faktor ancaman (threats) sebesar 2,64.

Skor pembobotan dari faktor internal dan eksternal akan digunakan untuk mencari titik kordinat dalam Grafik analisis SWOT. Rumus yang digunakan untuk memperoleh titik kordinat tersebut adalah skor S dikurangi skor W dan skor $\mathrm{O}$ di kurangi dengan skor $\mathrm{T}$ sehingga titik kordinat pada grafik SWOT adalah: $3,66-2,8 ; 3,66-2,64=0,86 ; 1,02$. Posisi koordinat grafik dapat dilihat pada Gambar 1.

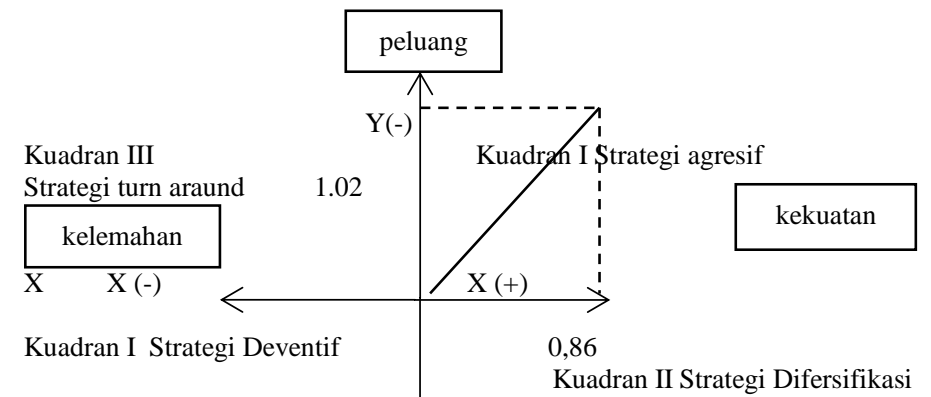

Y (-)

ancaman

Gambar 1 . Grafik Posisi Strategi Pengembangan Usaha Biskuit Jagung

Gambar 1. menunjukan bahwa titik koordinat $(0,86 ; 1,02)$ berada pada kuadran 1 (agresif) yang berarti usaha biskuit jagung pada kelompok wanita tani lestari memiliki kekuatan dan peluang yang sangat baik, sehingga kelompok wanita tani lestari dapat memanfaatkan peluang dan kekuatan yang ada untuk mengembangkan usaha biskuit jagung selanjutnya.

Untuk menentukan alternatif strategi usaha Biskuit Jagung pada Kelompok Wanita Tani Lestari maka di susun matriks SWOT yang menggambarkan secara jelas bagaimana peluang dan ancaman dari usaha biskuit jagung tersebut dapat di sesuaikan dengan kekuatan dan kelemahan yang ada. Untuk lebih jelasnya dapat di lihat pada Tabel 3

Tabel 3. Matriks SWOT Usaha Biskuit Jagung

\begin{tabular}{|c|c|c|}
\hline EFE & $\begin{array}{l}\text { Strength (S) } \\
\text { S1 kontiunitas produksi } \\
\text { S3 kebersamaan kelompok } \\
\text { S4 sudah lama mengusahakan } \\
\text { S4 Memiliki kekhasan produk } \\
\text { dari segirasa,tekstur dan } \\
\text { penampilan produk } \\
\text { S5 ketersediaan bahan baku }\end{array}$ & $\begin{array}{l}\text { Weaknesses (W) } \\
\text { W1 Kualitas SDM } \\
\text { W2 Teknologi Produksi } \\
\text { W3 Daya simpan biskuit jagung } \\
\text { W4 Promosi belum efektif } \\
\text { W5 Modal dalam produksi } \\
\text { W6 belum memiliki surat ijin usaha } \\
\text { W7 belum memiliki surat ijin } \\
\text { BPOM }\end{array}$ \\
\hline $\begin{array}{l}\text { Opportunities }(\mathbf{O}) \\
\text { O1 Adanya dukungan } \\
\text { Pemerintah } \\
\text { O2banyak konsumenbaik di } \\
\text { dalam daerah maupun di luar } \\
\text { daerah } \\
\text { O3 tersedianya pasar } \\
\text { O4 Kondisi lirngkungan } \\
\text { mendukung } \\
\text { O5 produk local }\end{array}$ & $\begin{array}{l}\text { Strategi S-O } \\
\text { SO1. memperluas permintaan } \\
\text { pasar dengan menjaga } \\
\text { ketrampilan yang tinggi dalam } \\
\text { memperhatikan kualitas produk. } \\
\text { SO2.Meningkatkan permintaan } \\
\text { pasar dari semangat produksi } \\
\text { dalam memperhatikan kondis } \\
\text { lingkungan, minat konsumen } \\
\text { yang ada dan kekhasan produk. }\end{array}$ & $\begin{array}{l}\text { Strategi W-O } \\
\text { WO1.Menjaga hubungan kemitraan } \\
\text { dengan pemerintah/lembaga- } \\
\text { lembaga terkait agar dapat } \\
\text { meningkatkan usaha biskuit jagung } \\
\text { dan kesejahteraan petani } \\
\text { (W1,W2,W3,W5,,O1,O3,) } \\
\text { WO2.Mempertahankan konsumen } \\
\text { dengan menjaga kondisi lingkungan } \\
\text { yang ada } \\
(\mathrm{W} 3, \mathrm{O} 2)\end{array}$ \\
\hline 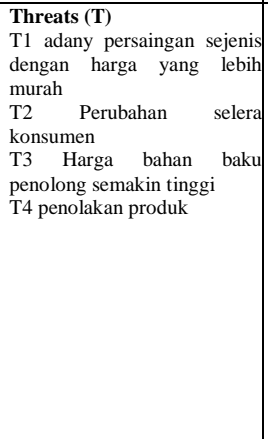 & $\begin{array}{l}\text { Strategi (S-T) } \\
\text { ST1.Meningkatkan selera } \\
\text { konsumen dari kualitas produk } \\
\text { yang baik, dengan menjaga } \\
\text { kekhasan produk dari segi rasa, } \\
\text { tekstur dan penampilan } \\
\text { produk.(S1,S2,S4,T1,T2) } \\
\text { ST2.Meningkatkan kualitas } \\
\text { produk yang baik agar dapat } \\
\text { menjaga resiko pengembalian } \\
\text { produk tidak terjaga }\end{array}$ & $\begin{array}{l}\text { Strategi (W-T) } \\
\text { WT1.Meningkatkan SDM melalui } \\
\text { pendidikan dan ketrampilan atau } \\
\text { skill dan teknologi produksi untuk } \\
\text { menjaga terjadinya persaingan } \\
\text { sejenis dengan harga yang lebih } \\
\text { murah } \\
\text { WT2.Meningkatkan promosi untuk } \\
\text { menjaga tidak terjadinya perubahan } \\
\text { selera konsumen. } \\
\text { WT3.Meningkatkan modal yang di } \\
\text { miliki agar dapat mengantisipas } \\
\text { tidak terjadinya perubahan harga } \\
\text { bahan baku penolong yang semakin } \\
\text { tinggi. } \\
\text { WT4 mengurus surat ijin } \\
\text { usaha,surat ijin BPOM untuk } \\
\text { mengantisipasi penolakan produk }\end{array}$ \\
\hline
\end{tabular}

Berdasarkan matriks SWOT pada Tabel 3. Maka dilanjutkan dengan mengkuantitatifkan strategi yang di dapat dengan mengadopsi model yang dikembangkan oleh Ommani (2011). Matriks QSPM di gunakan untuk mengevaluasi dan memilih strategi - strategi terbaik yang paling utama yang harus di lakukan oleh kelompok Wanita Tani Lestari dalam mengembangkan usaha Biskuit Jagung. Hasil kualifikasi sebagaimana di tampilkan pada Tabel 4

Tabel 4. Matriks QSPM Strategi Usaha Biskuit Jagung

\begin{tabular}{|c|c|c|c|c|c|c|c|c|c|}
\hline \multirow{2}{*}{$\begin{array}{c}\text { KEY } \\
\text { FAKTORS }\end{array}$} & \multirow{2}{*}{ weight } & \multicolumn{2}{|c|}{ WT1 } & \multicolumn{2}{|c|}{ WT2 } & \multicolumn{2}{|c|}{ WT3 } & \multicolumn{2}{|c|}{ WT4 } \\
\hline & & AS & TAS & AS & TAS & $\mathrm{AS}$ & TAS & AS & TAS \\
\hline $\mathrm{O} 1$ & 0.22 & 4 & 0.88 & 2 & 0.44 & 4 & 0.88 & 3 & 0.66 \\
\hline $\mathrm{O} 2$ & 0.22 & 3 & 0.66 & 3 & 0.66 & 3 & 0.66 & 2 & 0.44 \\
\hline $\mathrm{O} 3$ & 0.17 & 3 & 0.51 & 2 & 0.34 & 4 & 0.68 & 2 & 0.34 \\
\hline O4 & 0.22 & 3 & 0.66 & 2 & 0.44 & 3 & 0.66 & 3 & 0.66 \\
\hline O5 & 0.17 & 2 & 0.34 & 1 & 0.17 & 4 & 0.68 & 3 & 0.51 \\
\hline $\mathrm{T} 1$ & 0.30 & 3 & 0.90 & 3 & 0.90 & 2 & 0.60 & 2 & 0.60 \\
\hline $\mathrm{T} 2$ & 0.30 & 3 & 0.90 & 2 & 0.60 & 4 & 1.20 & 2 & 0.60 \\
\hline $\mathrm{T} 3$ & 0.20 & 2 & 0.40 & 3 & 0.60 & 2 & 0.40 & 3 & 0.60 \\
\hline $\mathrm{T} 4$ & 0.20 & 2 & 0.40 & 4 & 0.80 & 2 & 0.40 & 1 & 0.20 \\
\hline S1 & 0.17 & 1 & 0.17 & 4 & 0.68 & 3 & 0.51 & 4 & 0.68 \\
\hline $\mathrm{S} 2$ & 0.22 & 4 & 0.88 & 2 & 0.44 & 2 & 0.44 & 3 & 0.66 \\
\hline S3 & 0.22 & 2 & 0.44 & 3 & 0.66 & 4 & 0.88 & 2 & 0.44 \\
\hline S4 & 0.22 & 3 & 0.66 & 3 & 0.66 & 3 & 0.66 & 3 & 0.66 \\
\hline S5 & 0.17 & 2 & 0.34 & 1 & 0.17 & 3 & 0.51 & 3 & 0.51 \\
\hline W1 & 0.20 & 1 & 0.20 & 2 & 0.40 & 3 & 0.60 & 1 & 0.20 \\
\hline W2 & 0.15 & 3 & 0.45 & 2 & 0.30 & 2 & 0.30 & 2 & 0.30 \\
\hline W3 & 0.10 & 4 & 0.40 & 3 & 0.30 & 2 & 0.20 & 3 & 0.30 \\
\hline W4 & 0.10 & 3 & 0.30 & 1 & 0.10 & 3 & 0.30 & 2 & 0.20 \\
\hline W5 & 0.15 & 2 & 0.30 & 3 & 0.45 & 2 & 0.30 & 3 & 0.45 \\
\hline W6 & 0.10 & 2 & 0.20 & 2 & 0.20 & 2 & 0.20 & 3 & 0.30 \\
\hline W7 & 0.20 & 2 & 0.40 & 3 & 0.60 & 3 & 0.60 & 4 & 0.80 \\
\hline STAS & & & 10.39 & & 9.91 & & 11.66 & & 10.11 \\
\hline priority & & & 2 & & 4 & & 1 & & 3 \\
\hline
\end{tabular}

Keterangan : AS (atractiviness score), TAS ( Total atractiviness score )

Sesuai hasil analisis matriks QSPM pada Tabel 4. ternyata strategi paling utama yang harus dilakukan yaitu:

STRATEGI 1 (WT3) : berdasarkan perhitungan WT3 yaitu meningkatkan modal yang di miliki agar dapat mengantisipasi terjadinya perubahan harga bahan baku penolong yang semakin tinggi. kelompok wanita tani lestari dapat meningkatkan modal produksi dengan cara memanfaatkan sumber-sumber permodalan misalnya melalui koperasi UKM , bank terdekat seperti bank BRI, BNI dan Bank Mandiri untuk membantu kelompok wanita tani lestari dengan menambah modal supaya dapat mengantisipasi kenaikan harga bahan baku penolong agar tetap meningkatkan produksi sehingga dapat memenuhi permintaan konsumen baik yang ada dalam daerah maupun yang ada di luar daerah TTU.

STRATEGI II (WT1) : berdasarkan perhitungan WT1 yaitu Meningkatkan SDM melalui pendidikan dan ketrampilan atau skill, dan teknologi produksi untuk menjaga terjadinya persaingan sejenis dengan harga yang lebih murah. kualitas SDM yang harus di miliki kelompok wanita tani lestari merupakan salah satu faktor penting dalam persaingan dengan produk yang lain, yakni bagaimana menciptakan SDM yang berkualitas dan memiliki ketrampilan serta berdaya saing yang tinggi, dalam memproduksi biskuit jagung. hal ini dapat di lihat dari tingkat pendidikan, karena pendidikan merupakan tuntutan yang harus di utamakan sehingga dapat menguatkan pertumbuhan kelompok wanita tani lestari dalam usaha biskuit jagung ke depan. sedangakn untuk meningkatkan ketrampilan dan meningkatkan keahlian bekerja kelompok wanita tani lestari dengan menggunakan teknologi modern dalam menciptakan produk lain dari jagung yang berkualitas agar kontiunitas pemasaran tetap terjaga dengan harga yang murah. Sedangkan untuk meningkatkan teknologi produksi, kelompok wanita tani lestari dapat menggunakan teknologi yang ada seperti : mesin penggiling yang berfungsi untuk menghaluskan dan menggiling jagung setelah di tumbuk hingga menjadi tepung jagung. Sealer (mesin pengemas) yang berfungsi sebagai alat perekat plastik saat pengemasan produk, karena dengan menggunakan perekat plastik ini hasilnya jauh lebih bagus jika dibandingkan dengan menggunakan api karena resiko penurunan kualitas jagung sangat besar akibat perekatannya tidak sempurna dan udara masuk ke dalam plastik maka rasa biskuit jagung tidak gurih lagi, dan dapat memakan waktu yang cukup lama dalam pengemasan. Alat timbang duduk yang berfungsi untuk mengukur volume biskuit jagung pada saat pengemasan agar kemasan produk sama volumenya dan mengukur bahan- bahan tambahan yang digunakan untuk memproduksi biskuit jagung agar kualitas produk yang dihasilkan tetap baik. Serta memasarkan biskuit jagung dengan volume yang bervariasi pula dari volume 100 gram sampai 200 gram dengan harga yang bervariasi pula guna memperluas pasaran dan meningkatkan pendapatan kelompok wanita tani lestari, sehingga dapat menjaga terjadinya persaingan dengan produk lain dengan harga yang murah.

STRATEGI III (WT4) : berdasarkan perhitungan WT4 yaitu Mengurus surat ijin usaha,surat ijin BPOM untuk mengantisipasi penolakan produk. kelompok wanita tani lestari mengurus surat BPOM dan PIRT usaha biskuit jagung agar konsumen yakin dan percaya bahwa produk biskuit jagung yang dihasilkan sudah higiniesdan legal atau bebas dari bahan kimia sehingga konsumen yakin untuk membeli produk biskuit jagung tersebut. Upaya ini terus menerus perlu di 
perhatikan guna meningkatkan volume penjualan , memperluas pasaran produk biskuit jagung, dan mengantisipasi penolakan produk oleh konsumen.

STRATEGI IV (WT2) : berdasarkan perhitungan WT2 yaitu Meningkatkan promosi semenarik mungkin untuk menjaga tidak terjadinya perubahan selera konsumen Artinya : kelompok wanita tani lestari harus mempromosikan produk olahan yang telah di produksi melalui : pameran pangan lokal, melalui radio lokal ,melalui surat kabar dan brosur, dengan menjelaskan keunggulan dan keunikan dari produk yang di tawarkan, baik dari proses pengolahan sampai pemasarannya. Sedangkan untuk mengantisipasi perubahan selera konsumen, kelompok wanita tani lestari dapat membuat biskuit jagung dengan rasa yang berbeda-beda, misalnya: rasa coklat, stroberi, nenas dan lain-lain. Sehingga konsumen tidak beralih ke produk lain.

\section{Simpulan}

Berdasarkan uraian hasil penelitian di atas dapat disimpulkan bahwa kelompok wanita tani lestari merupakan salah satu kelompok tani yang berada di desa subun tualele, kecamatan insana barat, yang di bentuk pada Tahun 2000, yang semua anggotanya terdiri dari para wanita dalam melakukan kegiatan usaha melalui pengolahan jagung menjadi biskuit jagung. Modal yang digunakan pada awal memulai usaha biskuit jagung adalah modal sendiri dari kelompok wanita tani lestari. Rata-rata kelompok wanita tani lestari sudah berpengalaman dalam melakukan usaha biskuit jagung baik dari proses pengolahan sampai dengan pemasaran. Proses pengolahan biskuit jagung ini dilakukan di ruang khusus milik kelompok wanita tani lestari yang masih bersifat tradisional dan relatif mudah, mulai dari pengadaan bahan baku, pengolahan biskuit jagung, pengemasan sampai pada pemasaran biskuit jagung. Jenis jagung yang digunakan sebagai bahan baku dalam memproduksi biskuit jagung adalah jagung mutiara (jagung kuning). Karena jenis jagung ini mempunyai sifat - sifat yang baik dari jenis -jenis jagung yang lain, sifat penting yang di miliki adalah berpotensi dan hasilnya jauh lebih tinggi dari jenis-jenis lainnya.

Berdasarkan grafik analisis SWOT titik koordinat 0,86 dan 1,02 berada pada kuadran 1 ( agresif) yang berarti usaha biskuit jagung pada kelompok wanita tani lestari Desa Subun Tualele memiliki kekuatan dan peluang yang sangat baik, sehingga kelompok wanita tani lestari dapat memanfaatkan peluang dan kekuatan yang ada untuk mengembangkan usaha biskuit jagung selanjutnya. Sesuai hasil analisis matriks QSPM di peroleh 4 strategi yang paling utama sampai yang terakhir yaitu : 1). meningkatkan modal yang di miliki agar dapat mengantisipasi terjadinya perubahan harga bahan baku penolong yang semakin tinggi melalui koperasi UKM, BRI, BNI, untuk menambah modal supaya dapat mengantisipasi kenaikan harga bahan baku penolong, agar tetap memproduksi biskuit jagung sehingga dapat memenuhi permintaan konsumen. 2). Meningkatkan SDM melalui pendidikan dan ketrampilan atau skill, dan teknologi produksi untuk menjaga terjadinya persaingan sejenis dengan harga yang lebih murah melalui menciptakan SDM yang berkualitas dan memiliki ketrampilan atau skill yang ada dalam melakukan usaha biskuit jagung, dengan menggunakan teknologi yang ada seperti: mesin penggiling, sealer, dan alat timbang duduk. 3). Mengurus surat ijin usaha,surat ijin BPOM untuk mengantisipasi penolakan produk, agar konsumen yakin dan percaya bahwa produk yang dihasilkan sudah higienes dan legal. 4). Meningkatkan promosi semenarik mungkin untuk menjaga tidak terjadinya perubahan selera konsumen melalui membuat iklan di Koran, mengikuti pameran pangan lokal, radio lokal, membuat brosur, serta menambah olahan biskuit jagung dengan rasa yang berbeda-beda, misalnya rasa coklat, stroberi, nenas dan lain-lain. sehingga konsumen tidak beralih ke produk lain.

\section{Pustaka}

Nazir, M. 1988. Metode Penelitian, Ghalia Indonesia: Jakarta

Ommani, Ahmad Reza. 2011. Strategies of Rural Development in Shoushtar Township of Iran (Applying SWOT method). Journal of American Science, 2011;7(1).

Rangkuti, F. 2001. Analisis SWOT Teknik Membedah Kasus Bisnis. PT Gramedia Pustaka Utama. Jakarta. Diakses 11 November 2015.

Rukmana, R. 2009. Usaha Tani Jagung. Kanisius, Jakarta 